\title{
Glutamine Metabolism Stimulates Intestinal Cell MAPKs by a cAMP-Inhibitable, Raf-Independent Mechanism
}

\author{
J. MARC RHOADS,* ROBERT A. ARGENZIO, ${ }^{\ddagger}$ WUNIAN CHEN,* LEE M. GRAVES, ${ }^{\S}$ LAURA L. LICATO,॥ \\ ANTHONY T. BLIKSLAGER, ${ }^{\ddagger}$ JUDY SMITH," JOHN GATZY," and DAVID A. BRENNER" \\ Departments of * Pediatrics, § Pharmacology, "Surgery, and "Medicine,University of North Carolina; ₹Department of Anatomy, Physiology, \\ and Radiological Sciences, North Carolina State University College of Veterinary Medicine; and Center in Gastrointestinal Biology and Disease, \\ Chapel Hill and Raleigh, North Carolina
}

Background \& Aims: Infectious diarrhea caused by viruses plus enterotoxigenic bacteria is often more severe than diarrhea induced by either pathogen alone. We postulated that the increased cell adenosine $3^{\prime}, 5^{\prime}$ cyclic monophosphate (CAMP) concentration observed during infection by enterotoxigenic organisms retards the intestinal repair process by blocking activation of mitogen-activated protein kinases (MAPKs) in proliferating intestinal cells. Methods: We evaluated the effects of glutamine on MAPK activity, thymidine incorporation, and cell number in glutamine-starved and -sufficient rat intestinal crypt cells (IEC-6). Results: In glutamine-starved cells, $10 \mathrm{mmol} / \mathrm{L}$ glutamine in the absence of serum stimulated $\left[{ }^{3} \mathrm{H}\right]$ thymidine incorporation 8 -fold. This effect was inhibited by $60 \%$ with 8-(4-chlorophenylthio) (8-CPT)-CAMP (100 $\mu \mathrm{mol} / \mathrm{L})+$ isobutyl methylxanthine $(100 \mu \mathrm{mol} / \mathrm{L})$. In cells not starved of glutamine, glutamine stimulated thymidine incorporation by 3-fold, and 8-CPT-CAMP completely blocked the mitogenic effect. Inhibition of proliferation by CAMP persisted for at least 68 hours after CAMP removal. In vitro kinase assays showed that glutamine signaling requires an intact ERK (extracellular signal-related kinase) pathway in unstarved cells. In starved cells, at least one other pathway (J NK) was activated by glutamine, and the mitogenic inhibition by 8-CPT-CAMP was incomplete. Other intestinal fuels (glucose and acetate) were not mitogenic. Conclusions: Increased levels of intracellular CAMP inhibit ERKs but only partially reduce glutaminestimulated proliferation in enterocytes adapted to low glutamine.

V iruses induce diarrhea by damaging the intestine, whereas enterotoxigenic bacteria elaborate toxins that induce intestinal salt and water secretion without injuring the mucosa. Diarrhea caused by viruses plus enterotoxigenic Escherichia coli is more severe than diarrhea induced by either agent alone.1-4 Repair of the intestinal epithelium is facilitated by luminal growth factors, such as epidermal growth factor (EGF), transforming growth factor (TGF)- $\alpha$, and insulin-like growth factor I, which are present in breast milk and interact with specific membrane receptors. ${ }^{5} M$ any of these factors activate protein kinases (M APK s), such as the extracellular signal-related kinases (ERK S) ERK-1 and ERK -2, as the initial step in signal transduction. ${ }^{6,7}$ A nother member of the MAPK family that may participate in inflammation and repair is c-J un nuclear kinase (JNK, also called stress-activated protein kinase, SAPK ). J N K phosphorylates and activates the nuclear transcription factor c-J un. ERK s phosphorylate and activate Elk-1 and other transcription factors. ${ }^{6,8,9}$

$\mathrm{N}$ ot only is there good evidence that MAPKs are activated by many types of mitogenic signals, but dominant mutations of Raf-1,10 MEK-1, and ERKS inhibit NIH-3T3 cell proliferation. Activating mutations of MEK-1 produced accelerated proliferation. ${ }^{11}$ A denosine 3', 5' -cyclic monophosphate (CAM P) has inhibitory or stimulatory effects on MAPK level and proliferation in a cell-type specific manner (reviewed by Graves and Lawrence ${ }^{12}$ ). CAMP may inhibit signal transduction through the MAPK pathway (Rat-1 cells) ${ }^{13-15}$ or the J N K pathway (T Iymphocytes). ${ }^{16}$ We hypothesized that CAM P would al so inhibit crypt cell proliferation, and we tested the ability of the trophic nutrient glutamine (GLN) to stimulate enterocyte proliferation in the presence of increased CAMP concentrations. The results of these studies have been presented in part previously. ${ }^{17}$

\footnotetext{
Abbreviations used in this paper: $A O A$, aminooxyacetate; CAMP, adenosine 3',5'-cyclic monophosphate; 8-CPT, 8-(4-chlorophenylthio); DMEM, Dulbecco's modified Eagle medium; DMEM-L, DMEM with low glucose; EGF, epidermal growth factor; ERK, extracellular signal-related kinase; EtOH, ethyl alcohol; GLN, glutamine; GST, glutathione S-transferase; J NK, C-J un nuclear kinase; MAPK, mitogenactivated protein kinase; MEK, MAPK kinase; SDS, sodium dodecyl sulfate; TGF- $\boldsymbol{\alpha}$, transforming growth factor $\boldsymbol{\alpha} ; \mathrm{QO}_{2}$, oxygen consumption.

(1) 2000 by the American Gastroenterological Association 0016-5085/00/\$10.00
} 


\section{Materials and Methods}

\section{Materials}

Acrylamide and bisacrylamide were obtained from N ational Diagnostics (Atlanta, GA), glutathione-Sepharose from Pharmacia Biotechnology (Piscataway, NJ), and antiERK antibody from Santa Cruz Biotechnology (Santa Cruz, CA ). Protease and phosphatase inhibitors (aprotinin, leupeptin, bestatin, 4-nitrophenyl phosphate, pepstatin, Pefabloc, dithiothreitol, and N onidet P-40 [N P-40]) were from Boehringer M annheim (Indianapolis, IN ). PD 98059 was from Cal biochem$\mathrm{N}$ ovabiochem (San Diego, CA). [ ${ }^{3 \mathrm{H}}$ ]T hymidine was obtained from Amersham (Arlington Heights, IL). [ $\gamma^{-32 P}$ ]Adenosine triphosphate (ATP) was purchased from DuPont (Boston, MA). All other chemicals were obtained from Sigma Chemical Co. (St. Louis, MO).

\section{Cells}

We studied the nontransformed crypt cell line IEC- 6 (ATCC, Gaithersburg, MD) at passage 9-20. Cells were grown in Dulbecco's modified Eagle medium (DMEM) with $4.5 \mathrm{~g} / \mathrm{L}$ glucose, $0.5 \mathrm{U} / \mathrm{mL}$ bovine insulin, and $5 \%$ fetal calf serum (Atlanta Biologicals, N orcross, GA). Cells were passaged every 3-4 days.

\section{$\left[{ }^{3} \mathrm{H}\right]$ Thymidine Incorporation Rates of Cultured Enterocytes}

IEC- 6 cells were plated in 24-well plates at a seeding density of $5 \times 10^{4}$ cells per well. Six hours after plating, cells were synchronized by serum starvation in DM EM-low glucose (DMEM-L) with no serum, low glucose $(5 \mathrm{mmol} / \mathrm{L})$, and "serum" levels of GLN $(0.7 \mathrm{mmol} / \mathrm{L})$ or no GLN for 18 hours. Cells were then treated for 24 hours. [ ${ }^{3} \mathrm{H}$ ] Thymidine $(2 \mu \mathrm{Ci})$ was incubated with treatments. Perchloric acid in methanol $(0.5 \mathrm{~mL}$ of $4 \mathrm{~mol} / \mathrm{L})$ was then added, and cellular proteins were allowed to precipitate overnight. The pellet was dissolved in Scintisafe Econo2 (Fisher Scientific, Fair Lawn, NJ) and counted in a $\beta$-scintillation counter (Beckman, Fullerton, CA).

\section{Raf Kinase, MEK, and ERK Immune Complex Assay}

IEC- 6 cells (70\% confluent) were starved of serum and GLN overnight. After exposure to GLN or inhibitors, cells were washed twice with cold phosphate-buffered saline (PBS). Lysis buffer $(20 \mathrm{mmol} / \mathrm{L}$ Tris, pH 7.5, 10\% glycerol, 1\% Triton $\mathrm{X}-100,137 \mathrm{mmol} / \mathrm{L} \mathrm{N} \mathrm{aCl}$, and $2 \mathrm{mmol} / \mathrm{L}$ EDTA) was added. Cells were scraped and collected in a microcentrifuge tube, centrifuged, and transferred to new tubes. Two micrograms of monoclonal antibody (anti-R af C-12, rabbit polyclonal antiMEK -1, or goat polyclonal anti-ERK 2; Santa Cruz Biotechnology) was added, and the tubes were rolled at $4^{\circ} \mathrm{C}$ for 1.5 hours. Protein A (Santa Cruz Biotechnology) slurry was added into each tube, and tubes were again rolled for 40 minutes. Beads were washed twice with cold lysis buffer and twice with cold PBS. For the Raf assay, $5 \mu \mathrm{L}$ recombinant MEK $(100 \mu \mathrm{g} / \mathrm{mL})$ was added, al ong with $0.3 \mu \mathrm{mol} / \mathrm{L}$ ATP and $6 \mu \mathrm{g}$ bovine serum al bumin. The mixture was shaken at $30^{\circ} \mathrm{C}$ for 10 minutes.

For both the R af and MEK assays, ERK $-2(20 \mu \mathrm{g} / \mathrm{mL}, 5 \mu \mathrm{L})$ was added for 10 minutes. For the ERK assay, $20 \mu \mathrm{L}$ of 20 $\mathrm{mmol} / \mathrm{L} \mathrm{HEPES}$, pH 7.5, was added to the beads. Finally, 20 $\mu \mathrm{L}$ of a mixture containing $75 \mu \mathrm{mol} / \mathrm{L}$ cold ATP, $2 \mu \mathrm{Ci} / \mathrm{mL}$ hot ATP, and $10 \mu \mathrm{g}$ of myelin basic protein was added, and the mixture was incubated for an additional 10 minutes. The reaction was stopped by adding $20 \mu \mathrm{L}$ EDTA $(100 \mathrm{mmol} / \mathrm{L}$, pH 7.5). Tubes were centifuged briefly, and $40 \mu \mathrm{L}$ was spotted onto P-81 filter paper (W hatman distributor; Hillsboro, OR). Papers were washed in $10 \%$ phosphoric acid for 10 minutes 6 times. Papers were rinsed in 100\% ethyl al cohol (EtOH) and dried with a hair drier before liquid scintillation counting.

\section{In Vitro Assays of Cellular JNK and ERK Activity}

Cells were collected with a cell lifter in Dignam C buffer $(420 \mathrm{mmol} / \mathrm{L} \mathrm{NaCl}, 1.5 \mathrm{mmol} / \mathrm{L} \mathrm{M} \mathrm{gCl}, 20 \mathrm{mmol} / \mathrm{L}$ HEPES [pH 7.0], $0.2 \mathrm{mmol} / \mathrm{L}$ EDTA, $25 \%$ glycerol, and 0.5 $\mathrm{mmol} / \mathrm{L}$ dithiothreitol) plus protease/phosphatase inhibitors $(0.5 \mathrm{mmol} / \mathrm{L}$ Pefabloc, $0.1 \mathrm{mmol} / \mathrm{L}$ 4-nitrophenyl phosphate, $0.04 \mathrm{mmol} / \mathrm{L} \beta$-glycerophosphate, $0.05 \mathrm{mmol} / \mathrm{L} \mathrm{N} \mathrm{a}_{3} \mathrm{VO}_{4}, 40$ $\mu \mathrm{g} / \mathrm{mL}$ bestatin, $2 \mu \mathrm{g} / \mathrm{mL}$ aprotinin, $0.54 \mu \mathrm{g} / \mathrm{mL}$ leupeptin, and $0.7 \mu \mathrm{g} / \mathrm{mL}$ pepstatin A). We used a solid-phase assay with a glutathione S-transferase (GST)-c-J un or GST-Elk fusion protein as the substrate. ${ }^{18}$ GST-cElk plasmid was a gift of $R$. Treisman (Transcription Laboratory, Imperial Cancer Research Fund, London, England); GST-c) un plasmid was a gift of $M$. $\mathrm{K}$ arin (University of California, San Diego). Substrate (1 $\mu \mathrm{g})$ was linked to GLN-Sepharose. For the JN K assay, $25 \mu \mathrm{g}$ of whole cell extract was mixed with the substrate, $1 \mu \mathrm{g}$ of GST - c-J un, in $300 \mu \mathrm{L} \mathrm{HBB}(20 \mathrm{mmol} / \mathrm{L}$ HEPES, pH 7.7, 50 $\mathrm{mmol} / \mathrm{L} \mathrm{N} \mathrm{aCl}, 0.1 \mathrm{mmol} / \mathrm{L}$ EDTA, $2.5 \mathrm{mmol} / \mathrm{L} \mathrm{M} \mathrm{gCl}, 0.5 \%$ Triton $X-100$, plus protease/phosphatase inhibitors), at $4^{\circ} \mathrm{C}$ for 3 hours. The GST-bound proteins were then washed 4 times with HBB and incubated with $4 \mathrm{mmol} / \mathrm{L} \mathrm{HEPES}, 2 \mathrm{mmol} / \mathrm{L}$ $\mathrm{M} \mathrm{gCl}_{2}, 4 \mathrm{mmol} / \mathrm{L} \beta$-glycerophosphate, $0.2 \mathrm{mmol} / \mathrm{L}$ dithiothreitol, $10 \mu \mathrm{mol} / \mathrm{L} \mathrm{N} \mathrm{a}_{3} \mathrm{VO}_{4}, 2 \mathrm{mmol} / \mathrm{L}$ p-nitrophenylphosphate, and $2 \mu \mathrm{mol} / \mathrm{L} \mathrm{ATP}$ (with $\left[\gamma^{-32 P}\right]$ ATP $>4000 \mathrm{Ci} / \mathrm{mmol}$ ), at $30^{\circ} \mathrm{C}$ for 30 minutes. The phosphorylated C-J un fusion protein was boiled in sodium dodecyl sulfate (SDS) sample buffer and loaded onto a $10 \%$ SDS-polyacrylamide gel with molecularweight standards. Equal loading was verified by Coomassie blue staining. Autoradiography/densitometry was used to quantify labeled GST-J un.

For the ERK assay, $5 \mu \mathrm{g}$ anti-Erk antibody mixture with protein A-Sepharose in RIPA (150 mmol/L N aCl, $50 \mathrm{mmol} / \mathrm{L}$ Tris-Cl [pH 7.2]), 1\% deoxycholate, $1 \%$ Triton X-100, and $0.1 \%$ SD S (plus protease/phosphatase inhibitors) were rotated for 2 hours at $4^{\circ} \mathrm{C}$. The mixture was sequentially washed once with $10 \%$ sucrose RIPA, H BN P (20 mmol/L HEPES [pH 7.5], $50 \mathrm{mmol} / \mathrm{L} \mathrm{N} \mathrm{aCl}, 0.1 \mathrm{mmol} / \mathrm{L}$ EDTA, $2.5 \mathrm{mmol} / \mathrm{L} \mathrm{M} \mathrm{gCl}$, and $0.5 \%$ NP-40), HB (HBNP without NP-40), and kinase reaction buffers (20 mmol/L HEPES [pH 7.5], $10 \mathrm{mmol} / \mathrm{L}$ $\mathrm{MgCl}_{2}, 2 \mathrm{mmol} / \mathrm{L}$ dithiothreitol, $0.1 \mathrm{mmol} / \mathrm{L} \mathrm{Na}_{3} \mathrm{VO}_{4}, 25$ 
$\mathrm{mmol} / \mathrm{L} \quad \beta$-glycerophosphate, and $10 \mathrm{mmol} / \mathrm{L}$ 4-nitrophenyl phosphate) and then incubated with $1 \mu \mathrm{g}$ substrate in $25 \mu \mathrm{L}$ of kinase reaction buffer for 30 minutes at $30^{\circ} \mathrm{C}$ and washed 3 times with $1 \times$ RIPA. The phosphorylation products were run on a $12.5 \%$ SDS-polyacrylamide gel. The gel was dried, and autoradiography with Phosphorimager analysis was used to quantify density of the bands.

\section{Oxygen Consumption}

After 16 hours of serum starvation, IEC- 6 cells were trypsinized and collected in DMEM -L medium. W e incubated $5 \times 10^{6}$ cells in $1 \mathrm{~mL}$ DMEM-L medium in water-jacketed vials with continuous stirring at $37^{\circ} \mathrm{C}$. After 2 minutes' equilibration with air and $10 \mu \mathrm{L} G L N$ with or without 8-(4-chlorophenylthio) (8-CPT)-CAM P, PD 98059, or aminooxyacetate $(A O A)$, the system was seal ed and oxygen consumption $\left(\mathrm{QO}_{2}\right)$ was measured by a polarographic Clarke el ectrode for 10 minutes. The prel iminary data showed that cell $\mathrm{QO}_{2}$ was stable for 15 minutes and then decreased slowly. Results are expressed as percent oxygen consumed per million cells per minute.

\section{Cell Cycle Study}

Cell culture and treatment followed the $\left[{ }^{3} \mathrm{H}\right]$ thymidine incorporation protocols. After treatment, cells were washed with cold PBS twice and then were trypsinized, centrifuged, and resuspended in a small volume of PBS. Ice-cold EtOH (700 $\mu \mathrm{L}$ ) was added for 5 minutes, and the cells were then washed twice with cold PBS. Cold propidium iodide solution $(500 \mu \mathrm{L}$, concentration of $50 \mathrm{mg} / \mathrm{mL}$ with $2 \mu \mathrm{g} / \mathrm{mL}$ ribonuclease and $0.1 \%$ Triton X-100) was added to $10^{7}$ cells. Fluorescence was analyzed with a Becton Dickinson FACScan flow cytometer (San J ose, CA). Single-perimeter histograms were collected on 100,000 single cells. Doublets were eliminated by pulse analysis.

\section{Cell Counting Study}

Cells were grown in culture, starved, and treated for these studies in the same manner as described in the $\left[{ }^{3} \mathrm{H}\right]$ thymidine experiments. Cells were counted after 10 minutes of trypsinization in a hemacytometer. Cells in each well were counted twice.

\section{Statistics}

Results are expressed as means \pm SE. Effects of treatment were assessed by the 1-way analysis of variance. Individual groups were compared with the post hoc Tukey test (SigmaStat; J andel Scientific, San R afael, CA).

\section{Results}

\section{Effect of GLN and 8-CPT-CAMP on DNA Synthesis Rate of IEC-6 Cells}

Cells were preincubated overnight in either a "starvation medium" without serum or GLN (to maximize the response to $G L N{ }^{19}$ ) or in serum-free medium with $0.7 \mathrm{mmol} / \mathrm{L} \mathrm{GLN}$ to mimic the GLN concentration in plasma ("sufficient"). GLN -sufficient cells responded to $10 \mathrm{mmol} / \mathrm{L}^{20} \mathrm{GLN}$ with a $3.8 \pm 0.3$-fold increase in $\left[{ }^{3} \mathrm{H}\right]$ thymidine incorporation, whereas in starved cells thymidine incorporation increased $8.5 \pm 0.2$-fold $(n=$ 3-4 observations). Total thymidine incorporation 24 hours after addition of $10 \mathrm{mmol} / \mathrm{L}$ GLN was similar in both GLN-starved or -sufficient cells: about 8-fold greater than thymidine incorporation in GLN -starved cells. ${ }^{1}$

We hypothesized that elevated 8-CРT-CAMP levels would inhibit MAPK $s$ and thereby reduce the intestinal cell proliferative response to GLN.${ }^{19}$ CA M P inhibited the thymidine incorporation of IEC- 6 cells after addition of $10 \mathrm{mmol} / \mathrm{L} \mathrm{GLN}$ in a concentration-dependent manner (Figure 1A ). The slopes of the CAM P dose-effect relationships for starved and sufficient cells showed that CAM P inhibition was greater in the sufficient cells, with $100 \%$ inhibition of GLN -stimulated thymidine incorporation at $100 \mu \mathrm{mol} / \mathrm{L} 8$-CPT-CAM P.

We compared the effects of GLN with EGF on $\left[{ }^{3} \mathrm{H}\right.$ ] thymidine incorporation with or without CAMP (Figure 1B ). EGF (without GLN) stimulated $\left[{ }^{3} \mathrm{H}\right]$ thymidine incorporation $2.2 \pm 0.2$-fold above rate of incorporation in starved cells; this effect was blocked $197 \%$ inhibition) by 8-CPT-CAM P ( $\mathrm{n}=11$ observations from 3 passages of cells; not shown). In GLN-sufficient (0.7 $\mathrm{mmol} / \mathrm{L}$ ) cells, EG F stimulated $\left[{ }^{3} \mathrm{H}\right.$ ] thymidine incorporation 3.8-fold; this effect was al so completely inhibited by 8-CРT-CAM P.

\section{Effect of CAMP on MAPK Induction by GLN and EGF}

We compared the effects of GLN with or without 3-CPT-CAMP on ERK and JNK induction. CAMP has been shown to inhibit their activation in many cell types. ${ }^{13-15,21}$ For the ERK assay, we used an in vitro kinase assay of whole-cell extracts, with the nucl ear target of ERK-1 and -2, GST-Elk, as the substrate. In these studies, cells were preincubated in nonstarvation media with $0.7 \mathrm{mmol} / \mathrm{L} \mathrm{GLN}$ and subsequently exposed to GLN or a positive control, EGF, for 5,15 , or 30 minutes. Other cells were exposed to GLN or EGF, plus 8-CPTCAMP (300 $\mu \mathrm{mol} / \mathrm{L})$ with isobutyl methylxanthine (IBMX; $100 \mu \mathrm{mol} / \mathrm{L})$.

GLN signals through ERK $s$ in IEC- 6 cells ${ }^{19}$ (Figure $2 \mathrm{~A}$ ). Elk phosphorylation increased significantly to $3.1 \pm$ 0.3 of control levels at 5 minutes after GLN exposure $(P<0.05)$. This effect was significantly reduced in cells exposed to 8-CPT-CAMP $(\sim 40 \%$ inhibition; $P<0.05)$. At 15 and 30 minutes, the level of ERK activity declined and was only slightly affected by 8-CPT-CAM P.

EGF treatment produced a maximal $(5.0 \pm 1.5$-fold $)$ 
activation of kinase activity at 5 minutes. (Figure 2; P $<$ 0.05). This stimulatory effect was inhibited $66 \%$ by coincubation of the cells with 8-CPT-CAMP $(P<0.05)$. The EGF treatment had a biphasic stimulatory effect. ERK activity was increased at 15 minutes by $3.9 \pm$ 1.3 -fold and at 30 minutes by $4.8 \pm 0.3$-fold $(P<0.05$ at 30 minutes). At 15 minutes, 8-CPT-CAMP inhibited the EGF effect by $50 \%$, whereas 8 -CPT-CAM P inhibition was $100 \%$ at 30 minutes $(P<0.05)$. The means of 3 experiments at 5 and 30 minutes are shown in the bar graph in Figure 2C.

\section{Effect of EGF and GLN on Raf Activity in IEC-6 Cells}

$R$ af kinase is the tyrosine-threonine kinase in the ERK pathway that is activated by Ras after EGF and insulin receptor activation. ${ }^{22} \mathrm{R}$ af has been proposed to be a major site for regulation of ERK activity by CAMP (via protein kinase A) and is inhibited by CAMP in many cell

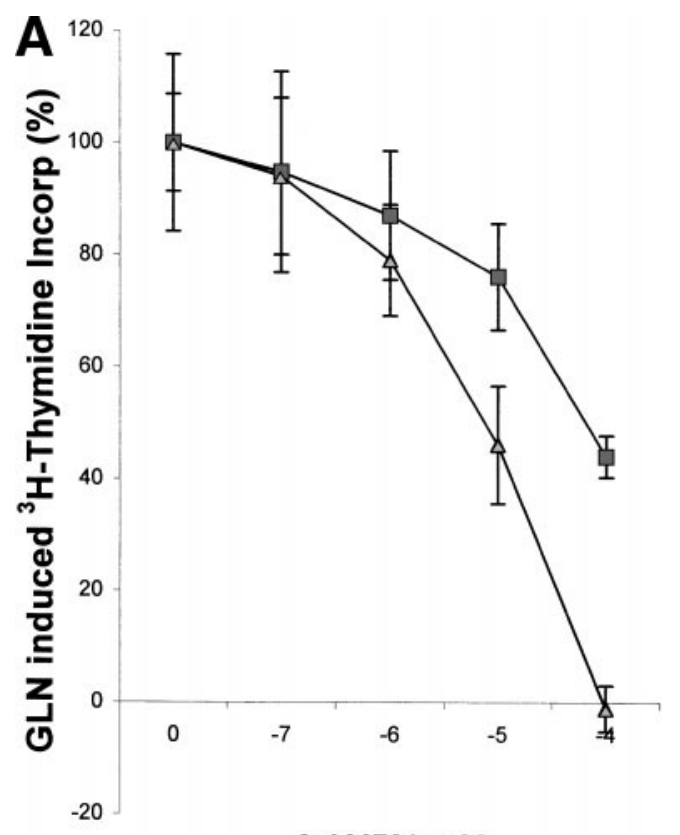

[CAMP] $\log M$

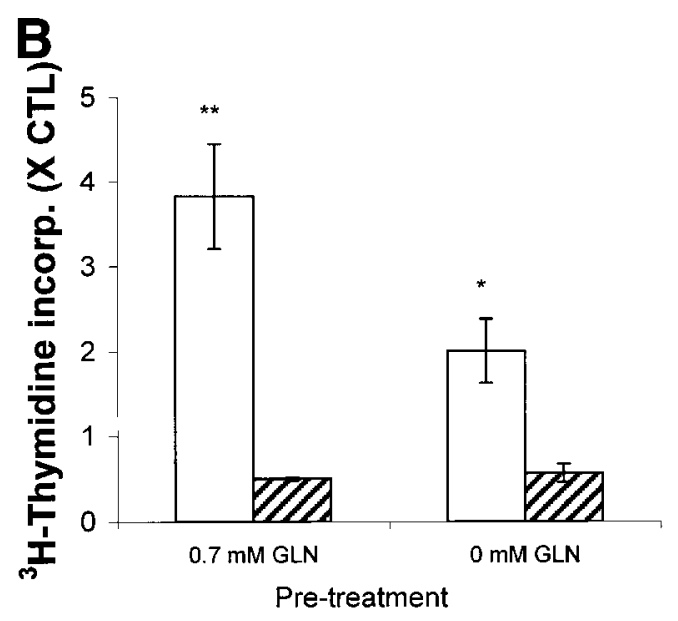

types. $^{12}$ In IEC-6 cells, EGF stimulated Raf kinase 14-fold, an effect that at 5 minutes was inhibited $75 \%$ by 8-CPT-CAMP (Figure 3). Raf continued to be activated 15 minutes after EGF treatment, by 9-fold, an effect blocked by 8-CPT-CAM P pretreatment (data not shown). Figure 3 shows that $R$ af phosphorylation/activation is not stimulated by GLN in IEC- 6 cells.

\section{Effect of GLN on MEK Activity in IEC- 6 Cells}

These results suggested that GLN activated an $R$ af-independent pathway; therefore, we examined MEK activation by GLN. MEK, al so called mitogen-activated protein kinase kinase, is immediately "downstream" of $R$ af in the signaling cascade. Figure 4 shows that GLN activates MEK almost as effectively as EGF in IEC- 6 cells, with a 2-fold activation at 5 minutes. As shown in the inset, the effect of GLN on MEK persisted with MEK stimulation by $1.6-1.7$-fold at 15 and 40 minutes $(P<$ 0.05). This effect of GLN was blocked by 8-CPT-CAM P (Figure 4).

Recently, a synthetic inhibitor, PD 98059, has been developed that is specific for MEK. PD98059 does not block JNK or p38 MAPK activity in other cell types. ${ }^{23}$ PD 98059 fully inhibits phenotypic changes attributed to MAPK activation in other cell types. As shown in Figure 4, PD 98059 (50 $\mu \mathrm{mol} / \mathrm{L})$ completely inhibited GLN stimulated MEK at 5 minutes.

Figure 1. (A) Effects of GLN and 8-CPT-CAMP on 24-hour IEC-6 cell proliferation. Three hours after plating IEC -6 cells ( $\sim 40 \%$ confluent) in 24-well plates, the cells were starved in serum-free DMEM-L and pretreated with GLN $(0.7 \mathrm{mmol} / \mathrm{L}$; Cells were then stimulated with $10 \mathrm{mmol} / \mathrm{L}$ GLN for 24 hours. 8-CPT-CAMP $(0-100 \mu \mathrm{mol} / \mathrm{L})$ with IBMX $(100 \mu \mathrm{mol} / \mathrm{L})$ was added to the medium 15 minutes before GLN treatment. [Methyl- $\mathrm{H}^{3}$ ]thymidine ( $2 \mu \mathrm{L} ; \mathrm{sp}$ act, $2.96 \mathrm{TBq} / \mathrm{mmol}, 80.0 \mathrm{Ci} / \mathrm{mmol}$ ) was added at the same time. Counts incorporated into perchloric acid-insoluble material are shown as multiples of control group (group treated with $0 \mathrm{mmol} / \mathrm{L}$ 8-CPT-CAMP). (B) Effect of 8-CPT-CAMP on 24-hour IEC-6 cell proliferation stimulated by EGF. $\square$, EGF; $\mathbb{Z}$, EGF + cAMP. Cells were either starved overnight of GLN or pretreated with $0.7 \mathrm{mmol} / \mathrm{L} \mathrm{GLN}$ in serum-free DMEM $-L$, and the GLN concentration was maintained after $20 \mathrm{ng} / \mathrm{mL}$ EGF was added. Twenty-four hours later, $\left[{ }^{3} \mathrm{H}\right]$ thymidine incorporation into acid-insoluble material was quantified as above. In paired plates, cells were exposed to EGF +8 -CPT-CAMP $\left(10^{-4} \mathrm{~mol} / \mathrm{L}\right)+$ IBMX $(100 \mu \mathrm{mol} / \mathrm{L})$. Data are compared with control cells. On the left side, control cells were pretreated with $0.7 \mathrm{mmol} / \mathrm{L} \mathrm{GLN}$ without EGF or 8-CPT-CAMP; thymidine incorporation rate was $19,800 \mathrm{cpm}$, and the rate increased $3.8 \pm 0.6$-fold after EGF treatment. After EGF + 8-CPT-CAMP treatment, the rate decreased to $0.5 \pm 0.02$-fold of control. $* * P<0.01$ compared with EGF alone. On the right side, control cells were treated overnight with $0 \mathrm{mmol} / \mathrm{L} \mathrm{GLN}$, and [ $\left.{ }^{3} \mathrm{H}\right]$ thymidine incorporation was $12,830 \mathrm{cpm}$. Treatment with EGF increased $\left[{ }^{3} \mathrm{H}\right]$ thymidine incorporation $2.01 \pm 0.4$-fold, whereas treatment with EGF +8 -CPT-CAMP reduced $\left[{ }^{3} \mathrm{H}\right]$ thymidine incorporation to $0.6 \pm$ 0.1 -fold the control value. $* P<0.05$ compared with EGF alone; $\mathrm{n}=$ 4. Control cells had baseline $\left[{ }^{3} \mathrm{H}\right]$ thymidine cpm of $1000-7000$ without GLN pretreatment and $5000-30,000 \mathrm{cpm}$ with $0.7 \mathrm{mmol} / \mathrm{L}$ GLN pretreatment. 


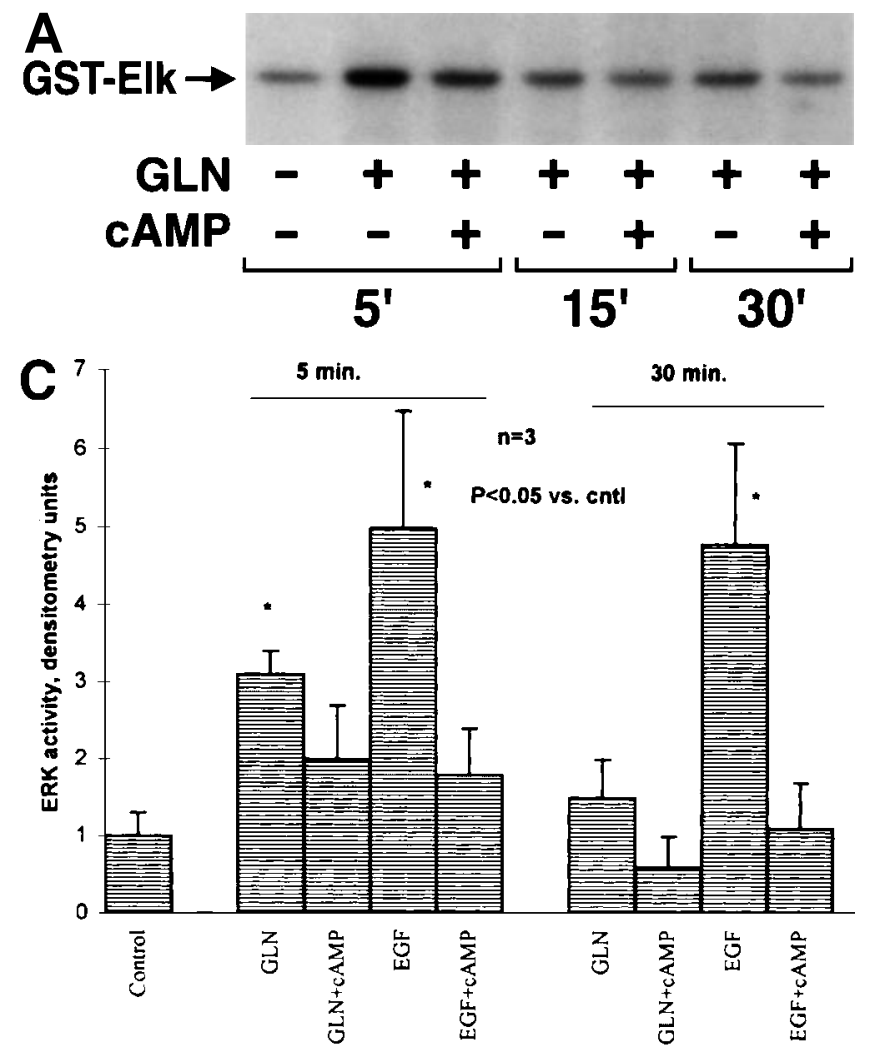

We have found that GLN has a much more potent impact on thymidine incorporation when cells are starved of serum and GLN overnight. ${ }^{19}$ Therefore, we determined if ERK signaling in GLN - "starved" cells is more effective or more resistant to PD98059 compared with control cells. Figure 5 shows that GLN and EGF activations of ERK $\mathrm{s}$ are similar in starved (left side) and

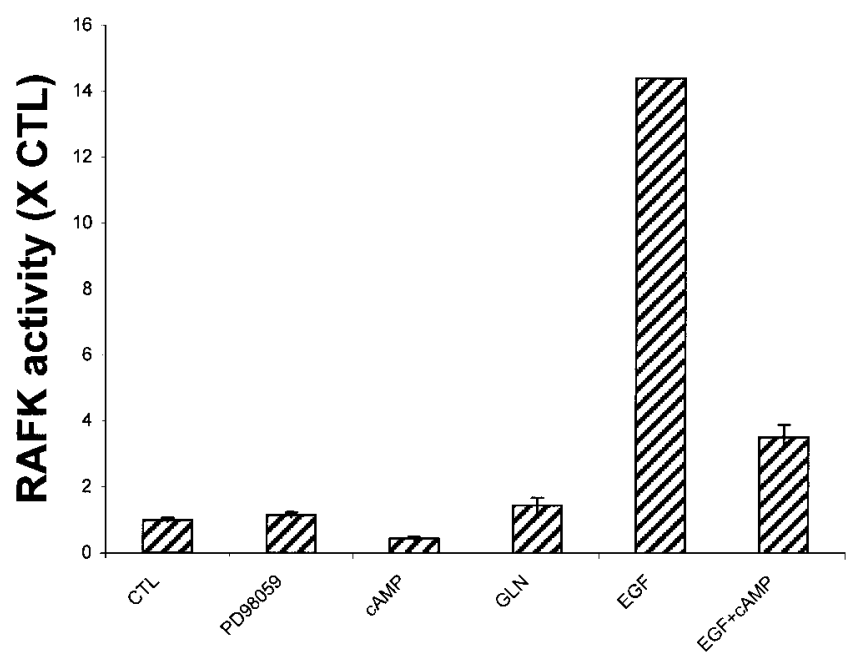

Figure 3. Effect of EGF and GLN on Raf kinase activity in IEC-6 cells. Cell were starved as described in Figure 2. In 1 group of cells, CAMP (333 $\mu \mathrm{mol} / \mathrm{L}+100 \mu \mathrm{mol} / \mathrm{L} \mathrm{IBMX}$ ) was added 15 minutes before EGF $(20 \mathrm{ng} / \mathrm{mL})$. After 5 minutes, cell lysates were collected and used for an immune complex assay for Raf (described in Materials and Methods). The increase in kinase activity above that of unstimulated cells is shown. $n=2-3$ except for EGF-stimulated cells, where $n=1$. Control cpm, 3140.

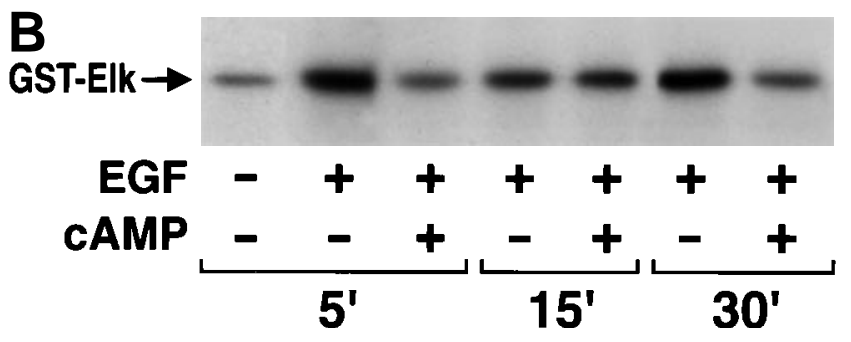

Figure 2. Effects of GLN, EGF, and CAMP on ERK activity of IEC-6 cells. Cells ( $\sim 70 \%$ confluent) in $100-\mathrm{mm}$ plastic dishes were starved in DMEM-L without GLN or serum for 24 hours and then were treated with (A) $10 \mathrm{mmol} / \mathrm{L} \mathrm{GLN}$ or (B) $20 \mathrm{ng} / \mathrm{mL}$ EGF with or without 8-CPT-CAMP (with IBMX) for 5,15 or 30 minutes. Cell samples were collected after washing twice in Dignam $C$ buffer and were allowed to phosphorylate GST-Elk beads in the presence of [ ${ }^{32}$ P]ATP after immunoprecipitation with anti-ERK specific antiserum. Phos phorylated GST-Elk was heated and separated by $12.5 \%$ SDS-polyacrylamide gel electrophoresis. Equal loading was determined by Coomassie blue staining. Dried gel was exposed to film for 3 days. The gel is representative of 3 experiments. (C) Averaged densitometry values (means $20 \pm$ SEM). $* P<0.05$ compared with control cell ERK activity. CAMP completely blocked ERK activation by GLN at 5 minutes and by EGF at 5 and 30 minutes.

unstarved cells (right side). Furthermore, PD 98059 is an effective inhibitor of MEK (and therefore the ERK pathway) regardless of GLN preexposure or starvation.

\section{Effect of GLN Oxidation on MEK Activation in IEC-6 Cells}

We used AOA (10 mmol/L), an inhibitor of transaminase reactions, to prevent conversion of GLN derived glutamate to $\alpha$-ketoglutarate and to inhibit the glutaminase reaction by producing a buildup of glutamate. We showed previously that AOA blocks GLN induction of ornithine decarboxylase, an enzyme implicated in cell proliferation. ${ }^{20}$ Figure 6 shows that 10 $\mathrm{mmol} / \mathrm{L} \mathrm{GLN}$ stimulates $\mathrm{Q}_{2}$ by IEC- 6 cells by 2 -fold. Stimulation was fully blocked by $10 \mathrm{mmol} / \mathrm{L} A O A$. AOA also completely inhibited MEK activation by GLN at 5 minutes (Figure 4).

We also determined if inhibition of MAPK signaling interferes with GLN's oxidative metabolism. Figure 6 shows that $\mathrm{GLN}$ stimulation of $\mathrm{QO}_{2}$ was not significantly reduced by 8 -CPT-CAMP $(300 \mu \mathrm{mol} / \mathrm{L})$ or PD 98059 (50 $\mu \mathrm{mol} / \mathrm{L})$.

PD98059 and 8-CPT-cAMP: Effects on GLN-Stimulated IEC-6 Cell Proliferation

We hypothesized that the early inhibition in ERK and MEK signaling in cells exposed to 8-CPT-CAMP would have a significant impact on subsequent DNA synthesis rate. 8-CPT-CAMP or PD 98059 inhibited 10 


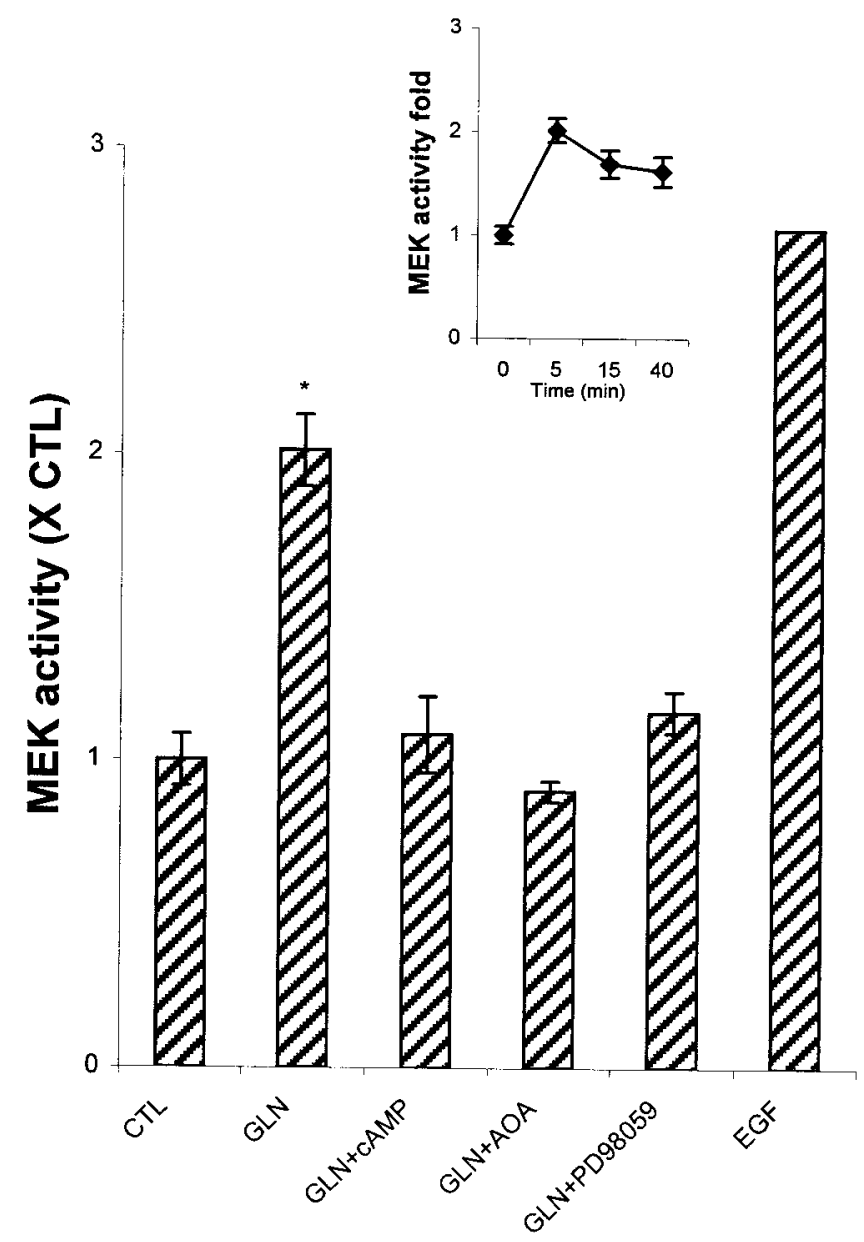

Figure 4. Effects of GLN on MEK activity of IEC-6 cells: inhibition by 8-CPT-CAMP, MEK inhibitor PD98059, and GLN metabolism inhibitor AOA. MEK is the substrate of Raf and has been shown to phosphorylate ERK-1 and ERK-2. Cells were starved as described in Figure 2.

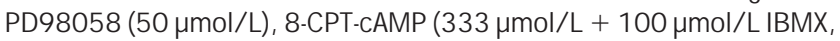
"CAMP"), and AOA (10 mmol/ L) were added 15 minutes before GLN $(10 \mathrm{mmol} / \mathrm{L})$ and EGF $(20 \mathrm{ng} / \mathrm{mL})$ were added. After 5 minutes of GLN or EGF treatment, collected cell lysates were used for an immune complex assay with myelin basic protein as the substrate (see Materials and Methods). $\mathrm{n}=2$. $* P<0.05$ compared with control cells. $n=3-4$ observations for each treatment; cpm for control cells, 2460. Inset shows kinetics of GLN-stimulated MEK activation (fold of control level).

$\mathrm{mmol} / \mathrm{L} \mathrm{GLN}$-stimulated thymidine incorporation to a similar extent (54\% inhibition by 8 -CPT-CAMP, 65\% inhibition by PD 98059) in GLN-starved IEC-6 cells (Figure 7, left panels). In GLN -sufficient enterocytes (0.7 $\mathrm{mmol} / \mathrm{L}$ GLN pretreated), 8-CPT-CAMP or PD 98059 completely blocked the GLN stimulation and reduced DN A synthesis bel ow basal levels (right panels).

To determine if inhibitors of cell proliferation had toxic effects on cultured intestinal cells, we treated cells with 8-CPT-CAMP + IBMX or PD 98059 for 24 hours, and we counted nonviable cells that take up trypan blue (1:50 dilution, 5-minute exposure, $\mathrm{n}=500$ cells, 2 passages). Control cells deprived of GLN and serum had 94.5\% viability. PD 98059 (50 $\mathrm{mmol} / \mathrm{L})$-treated cells had

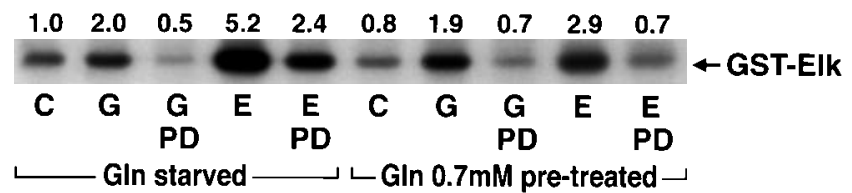

Figure 5. Effect of PD98059 on ERK activity of GLN-starved or GLN-sufficient cells. Whole-cell extracts were prepared from IEC-6 cells starved of GLN overnight or pretreated with $0.7 \mathrm{mmol} / \mathrm{L} \mathrm{GLN}$ and subs equently exposed to GLN (G, $10 \mathrm{mmol} / \mathrm{L})$ or EGF (E, $20 \mathrm{ng} / \mathrm{mL})$ or no treatment (control, C) for 10 minutes. In vitro ERK activity was assayed with GST-Elk as the substrate. Some preparations were exposed to GLN or EGF combined with PD98059 (PD, $50 \mu \mathrm{mol} / \mathrm{L}$ ). Relative densitometry values are shown at the top. One of 2 similar blots.

92.3\% viability. Of cells treated with 8-CPT-CAM P (300 $\mu \mathrm{mol} / \mathrm{L})+\mathrm{IBMX}(100 \mu \mathrm{mol} / \mathrm{L}), 96.4 \%$ remained viable. In summary, we found no evidence that either 8-CPTCAMP or PD 98059 was toxic.

GLN is a precursor of purines and pyrimidines. ${ }^{24}$ To confirm that GLN stimulates IEC- 6 cell proliferation, rather than thymidine incorporation into DN A alone, we plated cells at a density of $10^{5} \mathrm{cells} /$ well and manually counted cells after trypsinization 24 hours later. Table 1 shows that GLN increased cell number by $68 \%(P<$ 0.05). This stimulation was blocked by CAMP and PD 98059. N ote that cells shifted from a glucose concentration of $5.5 \mathrm{mmol} / \mathrm{L}$ (DMEM-L) to a concentration of $25 \mathrm{mmol} / \mathrm{L}$ in the absence of GLN had no increase in cell number. Similarly, the addition of the intestinal fuel ${ }^{25}$ acetic acid $(10 \mathrm{mmol} / \mathrm{L})$ did not stimulate mitogenesis. (A cetic acid at this concentration decreased the pH of the media by $0.4 \mathrm{pH}$ units, which could have partially reduced a mitogenic effect.)

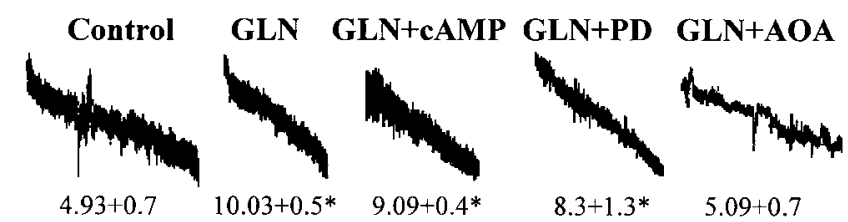

* Compared to Control, $\mathrm{P}<0.05(\mathrm{n}=3 \sim 5),\left(\mu 1 \mathrm{O}_{2} / \mathrm{ml} / \mathrm{h} / 10^{6}\right.$ IEC- 6 cells $)$

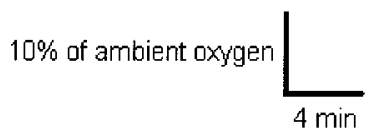

Figure 6. Effect of $A O A, C A M P$, and PD98059 on GLN-stimulated $\mathrm{QO}_{2}$ by IEC- 6 cells. After 24 -hour starvation, $5 \times 10^{6}$ IEC- 6 cells in DMEM-L were equilibrated with air for 2 minutes in a continuously stirred chamber with a Clarke-type electrode for the detection of $\mathrm{PO}_{2}$. Vehicle (control) or an agent in vehicle was added, and $\mathrm{QO}_{2}$ was recorded for 8 minutes. Cells were exposed to vehicle or agent only once. Representative traces are shown for each treatment with means for 4 replications below. Treatments were as follows: Control, GLN-starved; GLN $10 \mathrm{mmol} / \mathrm{L} ; \mathrm{GLN}+8$-cpt-CAMP, $300 \mu \mathrm{mol} / \mathrm{L} ; \mathrm{GLN}+$ PD98059, 50 $\mu \mathrm{mol} / \mathrm{L}$; GLN + AOA, $10 \mathrm{mmol} / \mathrm{L}$. 


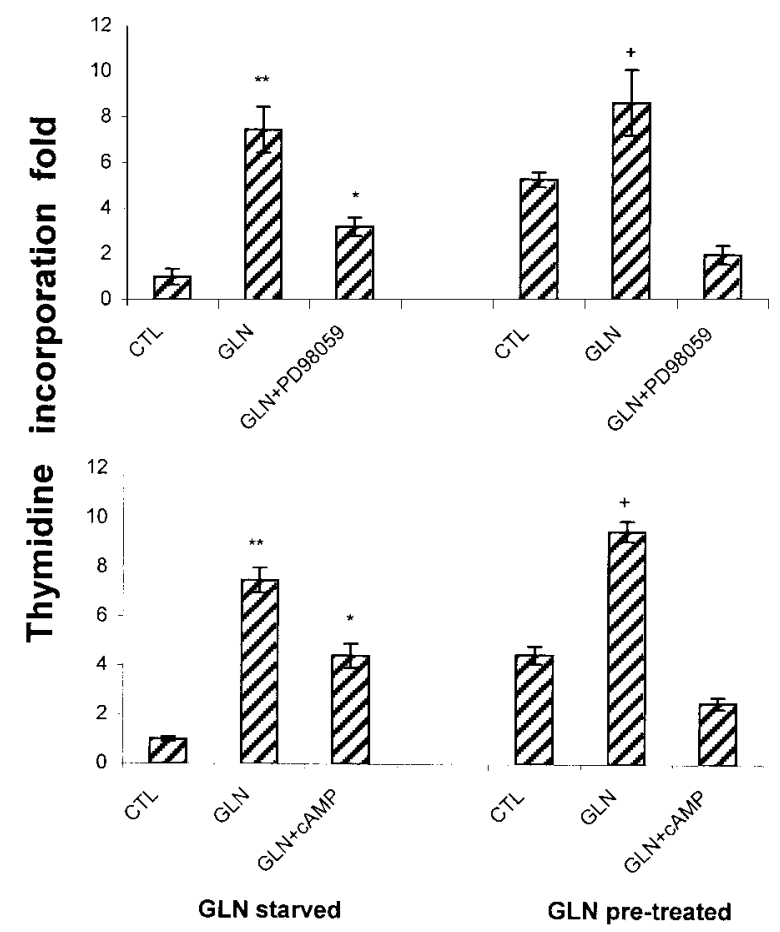

Figure 7. Effect of GLN, CAMP, and PD98059 on proliferation of GLN-starved and -sufficient IEC-6 cells. Cell starvation and thymidine incorporation assay were identical to those shown in Figure 1. CAMP (333 $\mu \mathrm{mol} / \mathrm{L}$ ) and PD98059 (50 $\mu \mathrm{mol} / \mathrm{L})$ were added 15 minutes before GLN (10 mmol/ L); thymidine incorporation at 24 hours estimated the cellular DNA synthesis rate. On the left, the 3 bars (upper and lower) show results from GLN-starved cells before stimulation with GLN. On the right, the 3 bars show data from cells pretreated overnight with $0.7 \mathrm{mmol} / \mathrm{L} \mathrm{GLN}$. $* P<0.05$ and $* * P<0.01$ compared with control (DMEM-L without GLN). $+P<0.05$ compared with 0.07 $\mathrm{mmol} / \mathrm{L} \mathrm{GLN}(\mathrm{n}=4)$. Control cpm is described in Figure 1 .

\section{Effect of 8-CPT-CAMP on GLN Activation of J NK}

To determineif the 8-CPT-CA M P-resistant proliferation in starved IEC-6 cells could be related to stimulation of thestress-activated protein kinase (SAPK), J un nuclear kinase $(\mathrm{JNK})$, cells were treated with 10 $\mathrm{mmol} / \mathrm{L} \mathrm{GLN}$ for 30 minutes after overnight starvation

Table 1. Effect of CAMP and Intestinal Fuels on IEC-6 Cell Number $\left(\times 10^{5}\right)$

\begin{tabular}{|c|c|c|c|c|c|c|}
\hline & DMEM-L & $\begin{array}{c}\text { GLN } \\
(10 \\
\mathrm{mmol} / \mathrm{L})\end{array}$ & $\begin{array}{c}\text { CAMP }+ \\
\text { GLN }\end{array}$ & $\begin{array}{l}\text { PD98059 } \\
+ \text { GLN }\end{array}$ & $\begin{array}{c}\text { D-Glucose } \\
(10 \\
\mathrm{mmol} / \mathrm{L})\end{array}$ & $\begin{array}{c}\text { Acetate } \\
(10 \\
\mathrm{mmol} / \mathrm{L})\end{array}$ \\
\hline Mean & 1.82 & $3.06^{a}$ & 1.95 & 2.35 & 1.88 & 1.91 \\
\hline SEM & 0.24 & 0.23 & 0.20 & 0.20 & 0.17 & 0.18 \\
\hline
\end{tabular}

NOTE. IEC-6 cells $\left(10^{5}\right)$ were plated in 24 -well plates overnight in DMEM-L without GLN or serum (DMEM-L, DMEM with $5.5 \mathrm{mmol} / \mathrm{L}$ glucose). The next day, nutrients with or without inhibitors were added for 24 hours, and cell number was counted 24 hours later. $n=6$ for each treatment. 8-CPT-CAMP concentration is $10^{-4} \mathrm{mmol} / \mathrm{L}$, combined with $100 \mu \mathrm{mol} / \mathrm{L} \mathrm{IBMX}$. PD98059 concentration is $50 \mu \mathrm{mol} / \mathrm{L}$. $\mathrm{n}=6$ observations

aP $<0.05$ compared with DMEM-L. and J N K was determined. As a positive control, we used TNF- $\alpha$ (10 $\mathrm{ng} / \mathrm{mL})$ to enhance JNK acitivity. JNK activity was assessed by an in vitro kinase assay that uses GST-c) un $\mathrm{N}$-terminus as the substrate $(\mathrm{n}=2)$. Figure 8 shows that $10 \mathrm{mmol} / \mathrm{L} \mathrm{GLN}$ with or without TNF- $\alpha$ increased JNK $\sim 4$-fold. 8-CPT-CAMP did not inhibit either GLN or TNF- $\alpha$-stimulated JNK activity.

\section{Effect of 8-CPT-cAMP Inhibition on the} $\mathrm{G}_{1} / \mathrm{S}$ Transition of the Enterocyte Cell Cycle

We sorted cells by fluorescence activation to determine the effect of 8-CPT-CAMP on the cell cycle. Cells were made quiescent by GLN/serum starvation overnight, and the next day the media was changed to media with GLN with or without 8-CPT-CAMP. As shown in Figure 9, 8-CPT-CAMP arrested progression of GLN sufficient cells through the cycle, with accumulation in $\mathrm{G}_{1}$ and depletion of cells in $\mathrm{G}_{2}(\mathrm{P}<0.05 ; \mathrm{n}=3)$. Table 2 shows that $G L N$ starvation al so produces $\mathrm{G}_{1} / \mathrm{S}$ arrest.

\section{Duration of CAMP and PD98059 Inhibition} of Proliferation

To determine if cell proliferation inhibition by CAMP and PD 98059 is reversible, IEC-6 cells were treated with CAMP or PD98059 for 4-24 hours; subsequently, CAMP and PD 98059 were washed out (Figure 10). Cells were allowed to recover without GLN for 8-20 hours before GLN stimulation. Cells were then counted after GLN (10 mmol/L) treatment for 24 hours (Figure $10 \mathrm{~A}$ ) and 48 hours (Figure 10B ). CA M P-treated cells did not recover despite washout of up to 20 hours and subsequent GLN treatment for 24 or 48 hours. PD 98059 treated cells similarly did not begin to proliferate after up

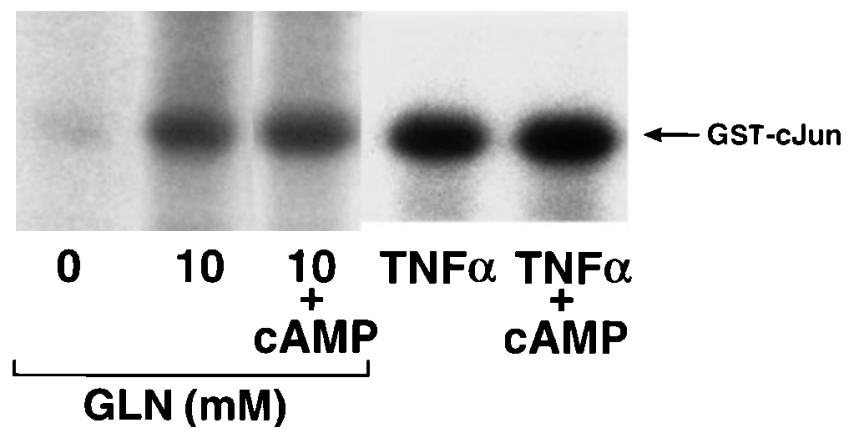

Figure 8. Effects of GLN, TNF- $\alpha$, and 8-CPT-CAMP on c-JUN kinase activity in IEC-6 cells. Cells in $100-\mathrm{mm}$ dishes ( $70 \%$ confluent) were starved in DMEM-L without serum or GLN for 24 hours. They were subsequently treated with $10 \mathrm{mmol} / \mathrm{L} \mathrm{GLN}$. TNF- $\alpha(10 \mathrm{ng} / \mathrm{mL})$ was added as a positive control. Cells in lanes 3 and 5 were exposed to 8-CPT-CAMP $(333 \mu \mathrm{mol} / \mathrm{L})+$ IBMX $(100 \mu \mathrm{mol} / \mathrm{L})$ for 10 minutes. Then the cells were washed and lysed by rotating in Dignam $C$ buffer. Lysate $(25 \mu \mathrm{g})$ was coincubated with GST-c-J un in the presence of [32P]ATP. Labeled GST-c-J un was separated by $10 \%$ SDS-polyacrylamide gel electrophoresis. Coomassie blue staining showed equal loading. Results are representative of 2 blots. 


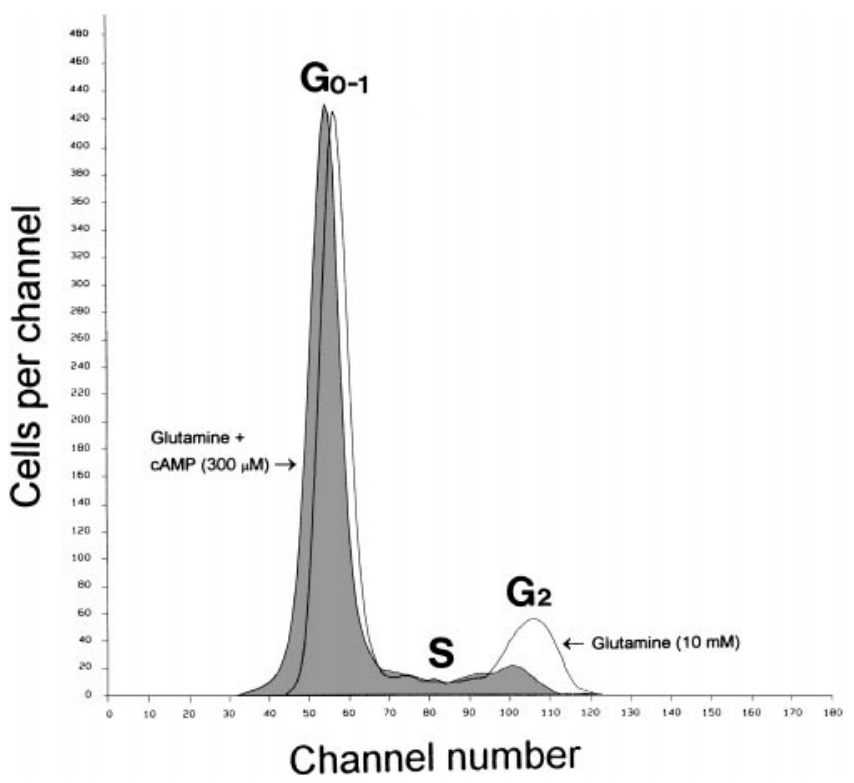

Figure 9. Effect of GLN and CAMP on the cell cycle of cultured enterocytes. After starvation and treatment as described in Figure 1, cells were fixed in $\mathrm{EtOH}$, stained with propidium iodide, and analyzed on a fluorescence-activated cell scanner. Single-perimeter histograms of 100,000 events were collected on aliquots of cells treated with $\mathrm{GLN}+8$-CPT-CAMP or GLN. The coefficient of variance of the $\mathrm{G}_{0-1}$ ("resting phase") peaks for both conditions was $<5.0$. S, S phase. An overlay of the 2 histograms shows the lack of progression through the cell cycle to the $\mathrm{G}_{2}$ stage in cells treated with 8-CPT-CAMP + GLN ( $n=$ $3)$. No obvious evidence for apoptos is is shown.

to 20 hours of PD 98059 washout, followed by 24 hours of GLN treatment. H owever, by 48 hours of GLN, cells treated 68 hours earlier with a 4-hour pulse of PD 98059 did show recovery. Cells exposed to PD 9805956 hours earlier showed no significant increase in cell number compared with control cells (GLN -and serum-starved). In these studies, cell number never exceeded $3.3 \times 10^{5}$, because cells had reached confluence at this density. These results were not biased by cells reaching confluence, because cells were only $80 \%-85 \%$ confluent at 24 hours and were $~ 95 \%$ confluent by 48 hours. The poor reversibility of the CAMP effect could be caused by sequestration of 8-CPT-CAM P within the cells, for example by CAM P-binding proteins.

Table 2. Effect of 8-CPT-cAMP on Cell Cycle Progression

\begin{tabular}{cccr}
\hline Glutamine & - & + & + \\
8-CPT-cAMP & - & - & + \\
\hline $\mathrm{G}_{1}$ & $79 \pm 1$ & $73 \pm 4$ & $85 \pm 0$ \\
$\mathrm{~S}$ & $10 \pm 1$ & $9 \pm 1$ & $7 \pm 1$ \\
$\mathrm{G}_{2}$ & $12 \pm 2$ & $18 \pm 5^{\mathrm{a}}$ & $8 \pm 1$ \\
\hline
\end{tabular}

NOTE. IEC- 6 cells were grown to $80 \%$ confluence and 6 hours later were exposed overnight to "starvation" conditions (no GLN or serum), GLN (10 mmol/ L), or GLN + 8-CPT-cAMP. Cells were then subjected to fluorescence-activated cell sorting. Data are means \pm SEM of 3 observations.

aP $<0.05$ compared with GLN + 8-CPT-CAMP.
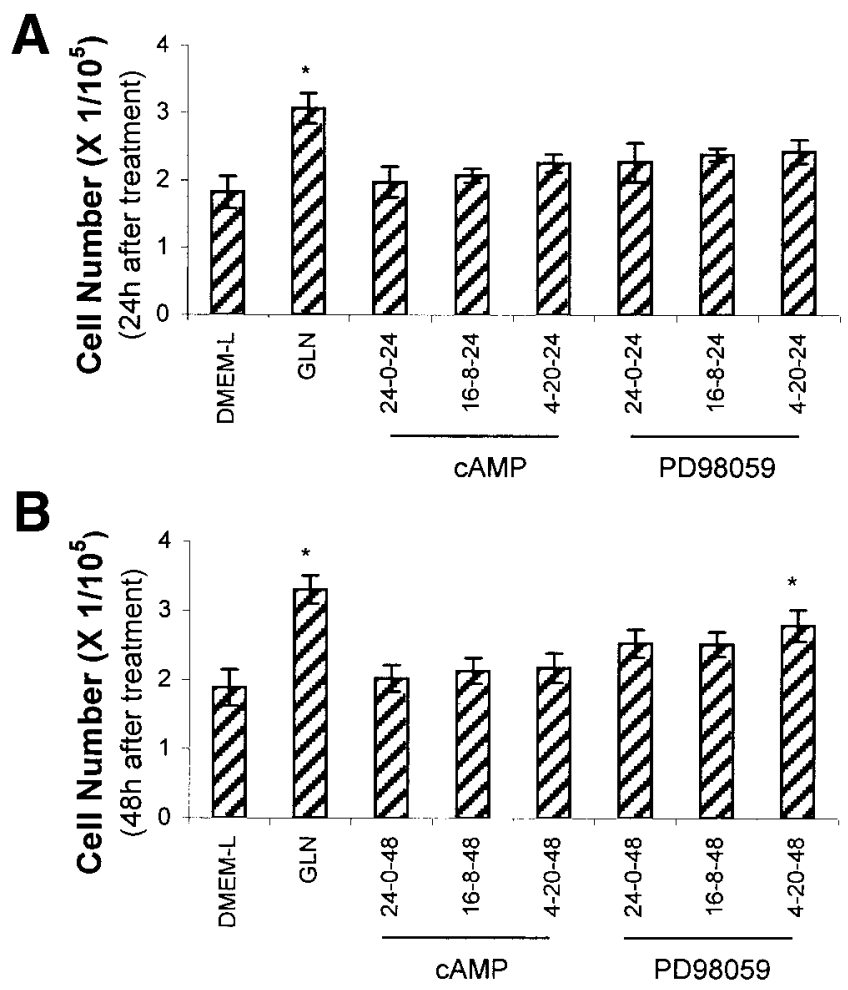

Figure 10. Determination of reversibility of CAMP inhibition and PD98059 inhibition of IEC-6 cell proliferation. Cells were plated in 24-well plastic plates at a density of $10^{5}$ cells/ well, washed, treated, and counted manually after trypsin treatment. Control cells were kept in DMEM-L. GLN was added at $10 \mathrm{mmol} / \mathrm{L}$. The 3 numbers beneath each bar refer to (1) the time (hour) of CAMP/IBMX or PD98059 treatment; (2) the length of time of "washout"; and (3) the time (hour) of GLN treatment. Cells were counted $(A) 24$ hours and $(B) 48$ hours after GLN treatment $(\mathrm{n}=6 ; * P<0.05)$.

\section{Discussion}

The major new findings of this report are (1) Lglutamine stimulates intestinal cell proliferation in "starved" intestinal cells, and this mitogenic effect is partially inhibited by blocking of ERK signaling; (2) CAMP inhibits proliferation in cultured small intestinal cell lines and, like the MEK inhibitor PD 98059, inhibits ERK s; (3) GLN stimulates ERK signaling through its metabolism; and (4) GLN signals through an Raf-independent mechanism.

\section{GLN and Proliferation of Starved Cells}

Intense interest has focused on GLN as a "nutraceutical" to enhance bowel function. Recent reports show GLN is trophic in the intestine, ${ }^{26,27}$ whereas others find no GLN effect on villus morphology. ${ }^{28-30}$ In general, minimal effects of GLN have been found in wellnourished animals with bowel resection and in wellnourished rats or humans receiving total parenteral nutrition supplemented with GLN. ${ }^{30,31}$ Trophic effects dominate reports about starved animals. For example, starved rats that are subsequently fed GLN-supple- 
mented total parenteral nutrition ${ }^{32}$ and rats fed a GLN supplemented diet after abdominal irradiation ${ }^{33}$ have a more normal intestinal villous architecture.

GLN metabolism has myriad physiological effects in this tissue. GLN fuels intestinal oxidative metabolism; serves as a precursor for nucleotide, arginine, and polyamine biosynthesis; and enhances intestinal blood flow. ${ }^{24}$ O ur findings support the concept that EGF is much more potent than GLN in mitogenic signaling, whereas GLN is a mandatory cofactor for downstream effects (e.g., thymidine incorporation) of EGF. GLN is an essential substrate for carbamoyl phosphate synthetase II (CPS II), the enzyme that catalyzes conversion of GLN to carbamoyl phosphate, an initial step in pyrimidine synthesis. $^{34}$ Given that DM EM contains $10 \mathrm{mmol} / \mathrm{L}$ glucose but no nucl eotides or nucl eosides, we speculate that a primary effect of GLN is to provide nucleotides for DNA synthesis. However, GLN utilization for nucleotides would not explain GLN 's rapid activation of the ERK or J N K pathways, or the $\sim 50 \%$ increase in $\left[{ }^{3} \mathrm{H}\right.$ ] thymidine incorporation observed in GLN -sufficient $(3.5 \mathrm{mmol} / \mathrm{L}$ ) enterocytes when reexposed to GLN. ${ }^{19}$ These findings point to a nonnutritive "trigger" or signaling effect of GLN on intestinal cell proliferation.

\section{CAMP Inhibits Intestinal Cell Proliferation}

Our interest in 8-CPT-CAM P originated from the observation that increased intestinal mucosal 8-CPTCAMP concentration is characteristic of not only toxigenic diarrhea (e.g., cholera) but also inflammatory enteropathies such as salmonel losis, when mucosal prostaglandin levels are high. ${ }^{35}$ In cholera toxin-exposed rabbit ileal loops, mucosal 8-CPT-cAM P content is increased to $\sim 1 \mu \mathrm{mol} / \mathrm{L}$, compared with less than half this value in control tissues. These values appear lower than the maximal concentrations needed to block proliferation in crypt enterocytes, but 8-CPT-CAMP may have leaked rapidly from cells used for these assays. Levels in rapidly washed upper crypt cells in Salmonela-induced enteritis reached as high as $50 \mathrm{pmol} / \mathrm{mg}$ protein, ${ }^{35}$ or about 5 $\mu \mathrm{mol} / \mathrm{L}$, assuming mucosal protein content is about 10 $\mathrm{g} / \mathrm{dL}$. This value is well within the range that inhibits proliferation in IEC-6 cells (Figure 1). It would be interesting to know if intestinal mucosal 8-CPT-CAMP levels remain el evated in children with chronic enteropathy and delayed villus repair.

Cell proliferation can be stimulated or inhibited by 8-CPT-CAM P in a cell-specific manner. ${ }^{12}$ CAM P "blocked" small intestinal IEC- 6 cells at the $G_{1} / S$ transition, an observation previously reported in other epithelial cells. ${ }^{36}$ A possible site of inhibition in our studies is at the level of $\mathrm{R}$ af and/or MEK, and our studies showed these kinases were inhibited by CAM P, as shown in previous investigations of mesenchymal cell lines. ${ }^{13,14}$

\section{CAMP and PD98059 Effects on ERKs and JNK}

MAPKs are prolinedirected kinases that are activated by phosphorylation of tyrosine and threonine residues. Three classes of MAPK $s$ have been identified, which share considerable sequence homology and are often, but not always, regulated in parallel during mitogenesis or cell injury: theER K s (extracellular signalrelated kinases), the stress-activated protein kinase c-J un $\mathrm{N}$-terminal kinase (JNK), and p38 MAPK, which is also activated by osmotic and other cellular stresses and during cell motility. This and our previous studies showed that GLN stimulates ERK functional activity in enterocytes. ${ }^{19}$ It is likely that the ERK s were a major site of inhibition of proliferation in 8-CPT-CAMP-treated cells in the present studies. Additional sites of inhibition by 8-CPT-CAMP are possible, resulting in inhibition of transition into S-phase of the cell cycle.

Inhibition of proliferation by 8-CPT-CAM P could have been mediated by inhibition of cellular processes such as mitochondrial metabolism or cytoskel etal rearrangement (independent of 8-CPT-CAMP effects on the ERK pathway). H owever, mitochondrial $\mathrm{QO}_{2}$ was not affected by 8-CPT-CAM P. Furthermore, PD 98059, a highly specific inhibitor of MEK 1 (the upstream activator of ERK -1 and $-2)^{23,37}$ completely blocked GLN - or EGF-stimulated proliferation and inhibited Elk-1 phosphorylation in nonstarved IEC-6 cells, without altering $\mathrm{QO}_{2}$. The inhibition of EGF-induced proliferation and ERK activity in IEC- 6 cells by PD 98059 has been demonstrated recently. ${ }^{38}$

It is possible that CAM P inhibits proliferation through mechanisms in addition to ERK inhibition. CAMP has been shown to produce cell cycle arrest by inhibiting the action of cdk-activating kinase and by increasing the activity of the cdk inhibitor p27 $7^{\mathrm{Kip1}}{ }^{39} \mathrm{H}$ owever, in that study, murine BAC1.2F5A macrophages were arrested at both $G_{1} / S$ and in $G_{2}$, whereas in our studies intestinal IEC- 6 cells were arrested only in $G_{1} / S$. Also, the similarity between MEK inhibition by PD 98059 and the effects of 8-CPT-CAM P suggests that a significant component of the CAM P inhibition is through MAP kinases. Additionally, we cannot rule out effects of 8-CPT-CAMP and PD 98059 on cell viability, but general toxicity of these inhibitors was ruled out by exclusion of trypan blue by IEC-6 cells exposed to 8-CPT-CAM P or PD 98059.

W e could not find previous studies examining activation of JNK s in small intestinal cell lines. Our studies showed that JNK is activated by mitogenic stimuli. ${ }^{19}$ 
J N K s may be activated during hyperthermia and oxidant stress, and are activated during apoptosis..$^{40}$ Interestingly, recent studies from the laboratory of $\mathrm{Ko}$ et al. ${ }^{41}$ have shown that GLN starvation induces apoptosis in IEC-6 cells. In our GLN-starved cells, J NK was not activated initially, although there was activation after GLN treatment. Although there is no known specific inhibitor of the JNK pathway, the use of PD98059 allowed us to separate 2 M APK pathways activated by GLN in proliferating IEC- 6 cells. We found no significant effect of PD 98059 on J N K activity (not shown) and only a partial effect of PD98059 in reducing $\left[{ }^{3} \mathrm{H}\right.$ ] thymidine incorporation response to GLN in "stressed" (starved) IEC-6 cells. W hile our studies demonstrate an effect of GLN on J N K in the starved cells, they do not rule out an effect of GLN on other pathways such as protein kinase $C$, phosphoinositol-3-kinase, or p38 MAPK.

\section{GLN Metabolism Bypasses Raf to \\ Stimulate MEK and ERK Induction}

$E G F$, insulin, and other growth factors are known to activate MEK via $\mathrm{R}$ af recruitment to membranebound ras, and Raf activation. There is evidence that growth signals may stimulate ERK activation in the absence of R af activation (Figures 3 and 4). In fact, MEK is often activated without a corresponding increase in $R$ af kinase activity. ${ }^{12}$ One example is in $G$ protein-coupled signal transduction in vascular smooth muscle cells. In these cells, angiotensin II stimulates ERK activation by an Ras- and Raf-independent pathway requiring activation of protein kinase $C .42$

We do not know the mechanism for initiation of GLN-stimulated mitogenesis. Research in other cell types suggests several possibilities. Kilberg et al. ${ }^{43}$ showed that amino acid starvation induced derepression of system $A$ amino acid transport activity within 2 hours. Amino acid refeeding (with $A$ system amino acids or GLN) increased cellular proliferation when added after starvation, perhaps by an effect on intracellular amino acid "loading." Additionally, cytosolic GLN, aspartate, and aminoisobutyrate repressed ribosomal protein messenger RNA levels. ${ }^{43}$ W hen cells were starved and subsequently refed, increased messenger RN A translation was observed. Other possibilities for how GLN signals mitogenesis include GLN-stimulated release of paracrine growth factors stored in a rapidly rel eased pool, or a rapid increase in polyamine synthesis via ornithine decarboxylase induction. ${ }^{20}$

\section{References}

1. Thouless ME, DiGiacomo RF, Deeb BJ. The effect of combined rotavirus and Escherichia coli infections in rabbits. Lab Anim Sci 1996;46:381-385.
2. Lecce JG, Balsbaugh RK, Clare DA, King MW. Rotavirus and hemolytic enteropathogenic Escherichia coli in weanling diarrhea of pigs. J Clin Microbiol 1982;16:715-723.

3. Uhnoo I, Olding-Stenkvist E, Kreuger A. Clinical features of acute gastroenteritis associated with rotavirus, enteric adenoviruses, and bacteria. Arch Dis Child 1986;61:732-738.

4. Haggard DL. Bovine enteric colibacillosis. Vet Clin North Am 1985;1:495-514.

5. Rhoads JM, Lecce JG, Keku EO, Kandil H, Woodard PW, Chen W, Liu SC, Fuller CR, Leary $\mathrm{HL}$, Ulshen $\mathrm{MH}$. Transforming growth factor-alpha stimulates jejunal mucosal recovery in piglet rotavirus enteritis. Pediatr Res 1995;38:173-181.

6. Hill CS, Treisman R. Transcriptional regulation by extracellular signals: mechanisms and specificity. Cell 1995;80:199-211.

7. Robinson MJ, Cobb MH. Mitogen-activated protein kinase pathways. Curr Opin Cell Biol 1997;9:180-186.

8. Derijard B, Hibi M, Wu I-H, Barrett T, Su B, Deng T, Karin M, Davis RJ. A protein kinase stimulated by UV light and Ha-Ras that binds and phosphorylates the c-Jun activation domain. Cell 1994;76: 1025-1037.

9. Marais R, Wynne J, Treisman R. The SRF accessory protein Elk-1 contains a growth factor-regulated transcriptional activation domain. Cell 1993;73:381-393.

10. Miltenberger RJ, Cortner J, Farnham PJ . An inhibitory Raf-1 mutant suppresses expression of a subset of v-raf-activated genes. J Biol Chem 1993;268:15674-15680.

11. Mansour SJ, Matten WT, Hermann AS, Candia JM, Rong S, Fukasawa K, Vande Woude GF, Ahn NG. Transformation of mammalian cells by constitutively active MAP kinase kinase. Science 1994;265:966-970.

12. Graves LM, Lawrence JC. Insulin, growth factors, and CAMP antagonism in the signal transduction pathways. TEM 1996;7: 43-50.

13. Wu J, Dent $P$, J elinek T, Wolfman A, Weber MJ, Sturgill TW. Inhibition of the EGF-activated MAP kinase signaling pathway by adenosine 3',5'-monophosphate. Science 1993;262:1065-1069.

14. Cook SJ, McCormick F. Inhibition by CAMP of Ras-dependent activation of Raf. Science 1993;262:1069-1072.

15. Burgering BMT, de Vries-Smits AMM, Medema RH, van Weeren PC, Tertoolen LGJ, Bos JL. Epidermal growth factor induces phosphorylation of extracellular signal-regulated kinase 2 via multiple pathways. Mol Cell Biol 1993;13:7248-7256.

16. Hsueh Y-P, Lai M-Z. C-Jun N-terminal kinase but not mitogenactivated protein kinase is sensitive to CAMP inhibition in $T$ lymphocytes. J Biol Chem 1995;270:18094-18098.

17. Rhoads M, Argenzio R, Chen W, Licato L, Rippe R, Brenner D. Cyclic AMP blocks intestinal cell proliferation by inhibiting mitogenactivated protein kinases (abstr). Gastroenterology 1997;112: A396.

18. Westwick JK, Brenner DA. Methods for analyzing C-Jun kinase. Methods Enzymol 1995;255:342-359.

19. Rhoads J M, Argenzio RA, Chen W, Rippe RA, Westwick JK, CoxAD, Berschneider HM, Brenner DA. L-Glutamine stimulates intestinal cell proliferation and activates mitogen-activated protein kinases. Am J Physiol 1997;35:G943-G953.

20. Kandil HL, Argenzio RA, Chen W, Berschneider HM, Stiles AD, Westwick JK, Rippe RA, Brenner DA, Rhoads JM. L-Glutamine and L-asparagine stimulate ornithine decarboxylase activity and proliferation in a porcine jejunal enterocyte line. Am J Physiol 1995;269: G591-G599.

21. Graves LM, Bornfeldt KE, Raines EW, Potts BC, MacDonald SG, Ross R, Krebs EG. Protein kinase $A$ antagonizes platelet-derived growth factor-induced signaling by mitogen-activated protein kinase in human arterial smooth muscle cells. Proc Natl Acad Sci USA 1993;90:300-310.

22. Davis RJ. The mitogen-activated protein kinase signal transduction pathway. Biol Chem 1993;268:553-556. 
23. Alessi DR, Cuenda A, Cohen P, Dudley DT, Saltiel AR. PD 908059 is a specific inhibitor of the activation of mitogen-activated protein kinase kinase in vitro and in vivo. J Biol Chem 1997;250:2748927494.

24. Neu J, Shenoy V, Chakrabarti R. Glutamine nutrition and metabolism: where do we go from here? FASEB J 1996;10:829-837.

25. Kight CE, Fleming SE. Nutrient oxidation by rat intestinal epithelial cells is concentration dependent. J Nutr 1993;121:869-878.

26. Sheppach W, Loges C, Bartram P, Christl SU, Richter F, Dusel G, Stehle $P$, Fuerst $P$, Kaspar $H$. Effect of free glutamine and alanyl-glutamine dipeptide on mucosal proliferation of the human ileum and colon. Gastroenterology 1994;107:429-434.

27. Fox AD, Kripke SA, DePaula J, Berman JM, Settle RG, Rombeau $J \mathrm{~L}$. Effect of a glutamine-supplemented enteral diet on methotrexate-induced enterocolitis. J Parenter Enter Nutr 1988;12:325331.

28. Wiren ME, Permert J, Skullman SP, Wang F, Larsson J. No differences in mucosal adaptive growth one week after intestinal resection in rats given enteral glutamine supplementation or deprived of glutamine. Eur J Surg 1996;162:489-498.

29. Michail S, Mohhamadpour H, Park JH, Vanderhoof JA. Effect of glutamine-supplemented enteral diet on mucosal adaptation following bowel resection. J Pediatr Gastroenterol Nutr 1995;21: 394-398.

30. Buchman AL. Glutamine: is it a conditionally required nutrient for the human gastrointestinal system? J Am Coll Nutr 1996;15:195196.

31. Van Der Hulst R, Van Kreel B, Von Meyenfeldt M, Brummer R-JM, Arends J -W, Deutz NEP, Soeters PB. Glutamine and the preservation of gut integrity. Lancet 1993;334:1363-1365.

32. Inoue Y, Grant JP, Snyder PJ. Effect of glutamine-supplemented total parenteral nutrition on recovery of the small intestine after starvation atrophy. J Parenter Enter Nutr 1993;17:165-170.

33. Klimberg VS, Souba WW, Dolson DJ, Salloum RM, Hautamaki RD, Plumley DA, Mendenhall WM, Bova FJ, Khan SR, Hackett RJ, Bland $\mathrm{KI}$, Copeland EM. Prophylactic glutamine protects the intestinal mucosa from radiation injury. Cancer 1990;66:62-68.

34. Sebolt JS, Aoki T, Eble JN, Glover JL, Weber G. Inactivation by acivicin of carbamoyl-phosphate synthetase II of human colon carcinoma. Biochem Pharmacol 1985;34:97-100.
35. Peterson JW, Molina NC, Houston CW, Fader RC. Elevated CAMP in intestinal epithelial cells during experimental cholera and salmonellosis. Toxicon 1983;21:761-775.

36. Ciardiello F, Pepe S, Bianco C, Baldassarre G, Ruggiero A, Selvam $M P$, Bianco AR, Tortora G. Down-regulation of RI alpha subunit of CAMP-dependent protein kinase induces growth inhibition of human mammary epithelial cells transformed by c-Ha-ras and cerbB-2 proto-oncogenes. Int J Cancer 1993;53:438-443.

37. Pumiglia KM, Decker SJ. Cell cycle arrest mediated by the MEK/ mitogen-activated protein kinase pathway. Proc Natl Acad Sci 1997;94:448-452.

38. Dionne S, Diagata ID, Kuemmele FM, Levy E, St.-Louis J, Srivastara AK, Levesque D, Seidman EG. Tyrosine kinase and MAPK inhibition of TNF-alpha- and EGF-stimulated IEC-6 cell growth. Biochem Biophys Res Commun 1998;242:146-150.

39. Kato J, Matsuoka M, Polyak K, Massague J, Sherr CJ. Cyclic AMP-induced G1 phase arrest mediated by an inhibitor (p27 Kip1) of cyclin-dependent kinase 4 activation. Cell 1994;79:487-496.

40. Xia Z, Dickens M, Raingeaud J, Davis RJ, Greenberg ME. Opposing effects of ERK and JNK-p38 MAP kinases on apoptosis. Science 1995;270:1326-1331.

41. Papaconstantinou HT, Hwang KO, Rajaraman S, Hellmich MR, Townsend CM J r, Ko TC. Glutamine deprivation induces apoptosis in intestinal epithelial cells. Surgery 1998;124:152-159.

42. Li X, Lee JW, Graves LM, Earp HS. Angiotensin II stimulates ERK via 2 pathways in epithelial cells: protein kinase $C$ suppresses a G-protein coupled receptor-EGF receptor transactivation pathway. EMBO J 1998;17:2574-2583.

43. Kilberg MS, Hutson RE, Laine RO. Amino acid-regulated gene expression in eukaryotic cells. FASEB J 1994;8:13-19.

Received February 25, 1999. Accepted September 7, 1999.

Address requests for reprints to: J. Marc Rhoads, M.D., Department of Pediatrics, University of North Carolina, Campus Box 7220, Chapel Hill, North Carolina 27599-7220. Fax: (919) 966-6841.

Supported by U.S. Department of Agriculture grants 94-37204-0448, DK 34987, and RO1-GM-51905. 